The respondents $(n=200)$ live in the small town where they attend school or in the neighboring villages. They filled a questionnaire of 88 dialect words that had been attested at the closest research points (Diszel, Kapolcs, Szentgál) of the Dialect Atlas of Hungarian and have a chance to be known among young speakers of today. 14 dialect words of the questionnaire were not used - and were not even known except one. 74 dialect words are used and 12 of them are used by more than half of the respondents. The study yielded nearly the same results as a former study of 2014 at the same school with the same methods. The author's hypothesis was confirmed: many young speakers know and use dialect words with the same denotata that can be found in the Dialect Atlas of Hungarian (the enormous amount of data of the atlas were collected between 1949 and 1964).

Keywords: dialect background, regionalisms, youngsters, dialect atlas, dialect word.

PARAPATICS ANDREA Pannon Egyetem

\title{
T UDOMÁNYTÖRTÉNET
}

\section{5 éve született Bárczi Géza*}

1. Bevezetés. Ennek az emlékezésnek az elsődleges célja az, hogy eleven képet fessen Bárczi Gézáról. Magam közelről ismerhettem őt: tanítását sok éven át hallgattam, s alkalmam volt személyiségének vonásait, sőt varázsát a közös munka során mind több oldalról felfedezni. Tanítványa voltam és vagyok, s ez életre szóló élményt jelent számomra. Ö maga immár 45 éve nincs közöttünk; az idő múlásával egyre kevesebben vagyunk, akik közvetíthetjük emlékét. Épp ezért személyes feladatunk e nagy tudós életművének és emberi alakjának a felidézése - amire a mostani évforduló kedvező lehetőséget kínál. A korábbi hasonló alkalmak emlékét számos köszöntő vagy megemlékező írás őrzi; ezekből itt-ott idézek majd. Elöre is kiemelném a közeli tanítvány, SZATHMÁRI ISTVÁN könyvét (1995), mely az életmü egészéröl átfogó képet ad.

2. Életútjának fó állomásai. Bárczi Géza Zomborban született 1894. január 9-én. Iskoláit is itt végezte. Korán elkezdett törökül tanulni: az volt a terve, hogy turkológus lesz. Megtanult eszperantóul; ezt a nyelvet gimnazistaként tanította is. Egy időben arra gondolt, hogy botanikus lesz. Ráismerhetünk ebben arra a színes érdeklődésre, amellyel általában a környező világ és az élet felé fordult, gyönyörködve annak különféle megnyilvánulásaiban. Bácskai gyerekkorára nézve tett egyszer egy emlékezetes, nyelvészeti érdekű megjegyzést: ő még hallott öreg papokat így misézni: [dominus vobiskum]. Történeti adalék ez az előző századforduló $s$-ező ejtésére a magyarországi egyházi latin nyelvben.

A budapesti e gyete men és az Eötvös Collegiumban végezte tanulmányait 1911-től, magyar-latin-görög szakon. A harmadév befejezése után, 1914 nyarán a Colle-

* Elhangzott 2019. november 19-én a Magyar Nyelvtudományi Társaság felolvasó ülésén.

DOI: 10.18349/MagyarNyelv.2020.3.351 
gium Párizsba küldte ösztöndíjasként. Szenvedélyesen hallgatta az egyetemi órákat - és itt érte a világháború.

Mint ellenséges ország állampolgárát több társával együtt internálótáborba zárták. Két és fél évig sínylődött itt, jórészt a „Fekete kolostor”-ban (Noirmoutier szigetén), amelyről emlékezetes képet fest Kuncz Aladár könyve. Bárczi egyik utolsó, posztumusz publikációja ehhez az élményvilághoz kapcsolódik. Egy frissen megjelent könyv (Lőrinczi 1975) nyomán azonnal felidézi saját emlékeit az internálásról, s meg is jelenteti azt egy folyóiratcikkben (BÁRCZI 1976). Megragadó személyes visszaemlékezés ez, tudósítás a fogolyéletről, annak mindennapos kínjairól, az ezeket időnként megtörő tevékenységekről (a vízhordásról, ami egy kis kimozdulást engedett a környező világba; Kuncz Aladár csellójátékáról az éjszakában, a csonka torony teraszán). Különösen elgondolkodtató az az emberismeret és elfogulatlanság, amellyel Bárczi környezete minden szereplőjét jellemzi. Ráismerhetünk itt egy alapvető vonására: az igazság szeretetére, a pontosság igényére és a rendkívüli szavahihetőségre. Ugyanerről tanúskodik egy másik, különleges dokumentum is: saját széljegyzetei abban a Kuncz Aladár-kötetben, melyet hagyatéka megörzött, s melyre egy kutató figyelme ráirányult (JENEY 2015).

Amikor teljesen legyengült egészségi állapota miatt a Vöröskereszt révén végre szabadul a fogságból, néhány svájci év következik Lausanne-ban. Valójában itt válik romanistává. Az egyetemen négy féléven át újlatin nyelveket tanulmányoz: a francia a fószakja, az olasz és a spanyol a mellékszakja. Legjobban az összehasonlító kutatások érdeklik. Svájcban ismerkedik meg majdani feleségével, B. Simond Renée-vel is. Hazatérése (1919) után Csillaghegyet választja lakhelyül: a Ráby Mátyás utca 26. alatti kis házban élt 1920-tól élete végéig.

Itthon rendkívül rövid idő alatt befejezi tanulmányait (magyar szakjából pár hónapon belül alapvizsgát és szakvizsgát is tesz), s 1920-ban megszerzi magyar-francia szakos tanári oklevelét. Minden amellett szól, hogy a romanisztika felé vegyen irányt. Kutatásait tekintve ez így is lett, amint erről pályája első szakaszának publikációi tanúskodnak. Ám az itthoni körülmények, föként a megfelelő intézményrendszer és tudományos háttér hiánya ezt nem tették lehetővé. Tegyük hozzá: a korszak történeti körülményei sem, hiszen 1919-1920 az ország egyetemei számára is nagy megpróbáltatásokat hozott.

Bárczi tehát kö zé p is k ola i tanár lett. Több mint 20 évig tanított gimnáziumban, előbb 10 évig az Eötvösben, majd újabb 12 éven át a Trefortban (akkori nevén a mintagimnáziumban, röviden a „Mintá”-ban). Ennek légkörét különösen szerette. Igen fontos része munkásságának a középiskolai francia tankönyvek írása. Ezek több évtizeden át meghatározó szerepet játszottak a közoktatásban, s még a II. világháború után is használták őket. Bárczi azt a franciás szellemet képviselte, amely a magyar értelmiségre általában is jellemző, s mely ebben a nehéz időszakban különösen fontos feladatának tartotta a francia kultúra eszményeinek terjesztését. Erről a témáról igen elmélyült, értő doktori disszertációt írt nemrég Párizsban CATHERINE TAMUSSIN (2018), aki Bárczi ilyen irányú tevékenységét is nagy elismeréssel méltatta.

Gimnáziumi munkájával párhuzamosan szerepet kap életében az e g y e t e m i o k t a tá s. Először Szegeden lesz magántanár 1932-ben (doktorátusát is itt szerezte 1926ban), azután Budapesten, 1938-ban. Számomra igazi meglepetés volt annak felfedezése, hogy (indexének tanúsága szerint) egy órájára Radnóti Miklós is járt. FERENCZ GYŐZŐ (2009: 173) Radnóti-monográfiájából kiderül: Radnóti, aki 1930 őszén iratkozott be 
a szegedi egyetemre, az 1932/33-as tanév első félévében Bárczi Géza „Chrétien de Troyes nyelve" címü előadását is hallgatta. Ezáltal a 12. század végi ófrancia udvari regény legnagyobb mesterének a világába kapott betekintést. Bárczinak Szegeddel való kapcsolatát ez az egyetem is számon tartja (vö. BÉKÉSI-TÓTH szerk. 1994). E korszak végén, 1939-ben a Magyar Tudományos Akadémia levelező tagja lett.

Igazi fordulópont életében a Magyar Szófejtő Szótár (1941). Ezzel jelenik meg - teljes fegyverzetben - Bárczi mint magyar nyelvész. Szakmai pályáján is fordulat következik be ekkor, miután Csüry Bálint váratlan halálával (1941) megüresedik a Debreceni Egyetem Magyar Nyelvtudományi Tanszékének tanszékvezető professzori állása. Az így előállt helyzetre PAIS DEZSŐ (1964: 130) így emlékezik vissza: „felvetették előttem, hogy ki lehetne az utóda. Azt feleltem: »Bárczi Géza!« Az ellenvetés rá így hangzott: »Hiszen az kiváló romanista.« »Igen!« - mondtam én. - »De ez nem akadályozza abban, hogy egyszersmind kitűnő magyar nyelvész lett légyen már eddig is, és ne legyen még inkább az, ha helyzetének lehetőségei segítik benne és kötelességei megkívánják tőle. « Meg vagyok győződve, azóta kiderült, hogy ritkán volt annyira igazam, mint akkor."

Az 1941 és 1952 közötti időszak Bárczi életének debreceni korszaka. Hallatlan intenzitású tanári munka kezdődik ekkor, hiszen a legkülönfélébb nyelvészeti tárgyak tanítása vár rá, a leíró és a történeti nyelvészet terén egyaránt. Lényeges mozzanat, hogy mivel Csüry Bálint munkásságában a nyelvjárástannak kitüntetett szerepe volt, Bárczi maga is feladatának tekinti, hogy folytassa az elődje által megkezdett munkát. Így kerül sor (a korábbi Magyar Népnyelv szerves folytatásaként) a Magyar Nyelvjárások évkönyv megindítására és igen fontos munkálatok (így a nyelvatlaszgyüjtés) megszervezésére. Foglalkozni kezd a régi magyar nyelvjárásokkal is; 1947-ben, amikor az Akadémia rendes tagja lesz, erről tartja székfoglaló előadását. Egyetemi munkásságából nőtt ki egy egész sereg szintézis, mely az 1950-es évek elejétől látott napvilágot az Egyetemi Magyar Nyelvészeti Füzetek sorozatban. Az első kötetekkel egy időben jelenik meg A Tihanyi apátság alapítólevele mint nyelvi emlék című könyve, mely a nyelvemlék-feldolgozásnak egy egészen új múfaját honosítja meg (BÁRCZI 1951a). Ennek elismeréseként kapja meg 1952-ben a Kossuth-díjat. A debreceni korszak a tekintetben is kiemelkedö, hogy itt és ekkor alakul ki a legközelebbi tanítványok köre, akikkel Bárczi egész életében kivételes szakmai és emberi kapcsolatban állt. Mindezekről később külön szólok.

Újabb fordulatot hoz pályáján az, hogy 1952-ben B u d a p e s te n létrehozzák az ELTE II. számú Magyar Nyelvészeti Tanszékét. Ezt Bárczi vezeti közel 20 éven át, egészen nyugdíjba meneteléig (1970). Ezzel új korszak kezdődik számára, miközben tudományos és tanári tevékenységének iránya változatlan marad. Külföldi megbecsülések is érik: a Finn Tudományos Akadémia tiszteleti tagja lesz. Születésének 70. és 80. évfordulójára köszöntő kötet készül (BENKÖ-LIGETI-PAIS 1963; E. ABAFFY-NAGY-ZELLIGER 1973), a századikra pedig emlékkönyv (SZATHMÁRI-E. ABAFFY-B. LÖRINCZY 1994).

Kiemelem most azt, hogy a két nyelvész tanszék vezetője hét éven át párhuzamosan Pais Dezső és Bárczi Géza volt. A köztük levő töretlen barátság és teljes szakmai szolidaritás, melyről a Pais-emlékkönyv Bárczitól származó előszava gyönyörüen tanúskodik (BÁRCZI 1956), eröt adhatott nekik azokban a küzdelmekben, amelyeket a nyelvtudomány érdekében kellett megvívniuk (amint erre Bárczi visszafogottan, de egyértelmüen utal). 1959-ben Benkő Loránd vette át az előbbi tanszék vezetését, s a Benkőés a Bárczi-tanszék barátsága ugyanolyan légkörben folytatódott tovább. Magam sokszor 
gondolok arra, hogy ha a nyelvész tanszékek vonzása a mai napig erős itt a Bölcsészkaron, ebben meghatározó szerepet játszik az a szellem, amelyet sok évtizede (immár két-három emberöltővel ezelőtt) Pais Dezső és Bárczi Géza tudományos és emberi habitusa alakított ki. Én magam életem nagy ajándékának tekintem, hogy ők ketten mestereim lehettek; bennem ők elválaszthatatlanul összetartoznak.

Van még egy apró, ám közérdekü megjegyzésem. Pais és Bárczi körében - a szeretet megnyilvánulásaként - számtalan személyes dokumentum keletkezett. Ezek egyúttal a Kruzsokhoz is kapcsolódnak, e legendás kávéházi körhöz, amelynek ök központi, hüséges tagjai voltak. Fennmaradtak Kubínyi László halhatatlan rajzai, a Tankerevet címü folyóirat számai, különféle korok stílusában írt imitációk, melyekkel őket tanítványaik vagy ők egymást köszöntötték. (Néhány ilyet én is őrzök Kázmér Miklós jóvoltából.) Mindezeket közkinccsé kellene tenni, például Intézetünk honlapján. Úgy gondolom, fontos felmutatni, milyen egy jó közösség, s milyen a vidám szellemben múvelt tudomány.

3. Bárczi Géza, a tudós: munkásságának fó irányai. Bárczi Géza tudományos munkásságáról átfogó képet adni röviden nem lehet. Ezért azt az utat választottam, hogy felvillantom azokat a fö tudományterületeket, amelyeket müvelt; mindegyik kapcsán megnevezek egy-két alapvető szintézist, kiemelek néhány tanulságot, s itt-ott utalok egy-egy rövidebb tanulmányra is, amelyet valamilyen okból különösen emlékezetesnek találok. A szakterületek tagolásában nem törekedtem szigorú kategorizálásra: arra jutottam ugyanis, hogy az életmű természete nem kedvez a merev felosztásnak. Bárczi Géza magyar nyelvtörténész volt, a szó legteljesebb értelmében. Ezzel együtt - széleskörü érdeklődésének köszönhetően - munkássága számos más területet is felölelt.

R o m a n i z z i k a. - Ó-francia hang- és alaktana (BÁRCZI 1933) valójában egyetemi hallgatók számára készült; a rövid előszó ugyanakkor jelzi, hogy szerzője gondolt a laikus érdeklődőkre és más szakterületek tudósaira is. Az olvasóknak ez az együtt-látása, el nem választása Bárczira nagyon jellemző, s ez már itt, legelső monográfiájában megmutatkozik. Részletes bibliográfiájával, szómutatójával, utalásaival és tömör, közérthető stílusával igazi hiánypótló munka. A szerző erről így szól az előszó végén (i. m. IV): „legalább a mi viszonyainkat tekintve, némikép úttörő munkát végeztem”.

Ugyancsak úttörő munkát végzett (ezúttal jóval kevesebb előzményre támaszkodva) A magyar nyelv francia jövevényszavai címü múvével (BÁRCZI 1938). E monográfiát részben már előkészítették első publikációi, melyek 1923-tól jelentek meg a Magyar Nyelvben, ilyen címekkel: Kilincs, Tálya, Furmint. Kiemelném azt a müvelődéstörténeti irányultságot, mellyel a magyar-francia kapcsolatokat (föként az Árpád-korra nézve) részletesen elemzi. Hozzáfüzöm, hogy BÁRCZI nem áll meg itt: teljes hosszmetszetet ad a francia hatásról, eljutva egészen saját koráig. E munkája máig alapmű. BENKÖ LORÁND (1963: 7) szerint bizonyosan ez volt az elindítója későbbi szótörténeti-etimológiai munkálkodásának. (BÁRCZI romanisztikai munkásságáról: KÁLMÁN-SZABICS 1988.)

Franciás irányultsága más müveit is áthatja. Amikor átfogó, nagy kérdések merülnek fel a magyar nyelvtörténettel kapcsolatban (mint az irodalmi nyelv kialakulásának kezdetei), rendkívül tanulságosak azok a párhuzamok, amelyeket egy másik nyelvből, nyelvcsaládból (vagy akár több nyelvcsaládból is) idéz. Bárczi szemléletét alapvetően meghatározza ez a tágasság. 
F o netika é s B e ve ze té s. - E két mü határozottan az egyetemi oktatás céljaira készült, a debreceni időszakban. Az első (BÁRCZI 1951b) mindössze 40 lapon ad hallatlanul világos áttekintést a fonetika fő kérdéseiről. Ezeket olyan megjegyzések, ábrák kísérik, amelyek például az írástörténet egyes kérdéseibe is bepillantást adnak. Kiemelendő, hogy az irodalomjegyzékben szereplő 28 cím közül 10 más nyelvű szakirodalomra (francia, német, orosz, angol munkákra) utal.

A Bevezetést (BÁRCZI 1953) kíváncsian üthetjük fel ma, ilyen kérdésekkel: kikre támaszkodott abban a korban, szemléletileg kik hatottak rá? A magyar szerzők közül GOMBOCZ ZOLTÁN és LAZICZIUS GYULA neve ugrik ki, a franciák közül pedig MEILLET, DAUZAT, GILliÉRON és SAUSSURE (persze az eredeti francia kiadás alapján). SAUSSURE kései magyar recepciójának ismeretében örömmel fogadja az olvasó, hogy már itt találkozik a langue és a parole kérdéskörével. De találunk e könyvben módszertani és nyelvtudomány-történeti fejezetet is. Mindez újraolvasásra hívogat. - Ehhez kapcsolódik egy számomra fontos kérdés: hatott-e SAUSSURE a magyar nyelvtörténészekre? Úgy gondolom, feltétlenül. Először GOMBOCZ (1924) ismertette a művet; maga Bárczi is hivatkozott óráin azokra az értékekre, amelyeket ez képvisel. (Egyszer hozzáfüzte: csak az a kár, hogy Saussure olyan mereven elválasztotta egymástól a szinkróniát és a diakróniát.) Az a törekvés, hogy rendszertörténetet írunk (nem pedig elemtörténetet), alapelve volt például A magyar nyelv történeti nyelvtanának - ez pedig saussure-i gondolatra épül.

H a n g tö r t é n e t. - Ezzel egy olyan munkához érkezünk (BÁRCZI 1958a), melyet valójában mindenki ismer. Esetleg közvetlenül, de még inkább azáltal, hogy ez jelenti a kiindulópontját minden olyan tankönyv hangtörténet-fejezetének, melyből az egyetemi ifjúság a mai napig tanul.

Történ et i a la kta n. - Ugyanezt mondhatjuk el Tőtanáról is (BÁRCZI 1958b), mely 60-70 lapon tökéletesen átfogó rendszerezést ad. Ez lényegét tekintve a mai napig áll (legfeljebb terminológiája módosult a leíró nyelvtan hatására). Szervesen kapcsolódik a Hangtörténethez, hiszen (amint Bárczi egyszer megjegyezte) a tőtan alkalmazott hangtörténet. - A magyar igeragozás története címü posztumusz monográfiája (1990) egyetemi szemináriumok keretében hangzott el korábban. Ezt a müvet - témájához illően - erős rendszerszerü szemlélet jellemzi.

A történeti alaktan területéről kiemelek két egészen rövid tanulmányt is, az életmü utolsó darabjai közül. Ezek azzal lepnek meg, hogy bámulatos célirányossággal adnak elő egy-egy megfejtési ötletet. Hosszú tudománytörténeti áttekintés helyett ilyen felütéssel kezdődik az első (BÁRCZI 1973: 210): „Általánosan elfogadott megállapítás, hogy a magyar föltételes módjel [...] két egymással összeforrott elemböl áll.” Jelzi, hogy az - $n$ háttere tisztázott, a második elemé nem; s ezek után az -á/-é összetevő eredetét vezeti le - kristálytiszta logikával - az elbeszélő múlt jeléből. A bizonyítás két pilléren nyugszik: az egyik a nyelvi rendszer, mely két igei alparadigma tökéletes párhuzamáról tanúskodik (vö. várék és várnék, vára és várna, R. várók és várnók stb.); a másik a különböző nyelvcsaládokból idézett analógiák sora (újlatin, szláv, germán nyelveké), ahol mindenütt megfigyelhető a feltételes mód jelének egy múltidőjelből való levezethetősége. Mindezt ragyogó okfejtéssel, két és fél lapon írja meg, olyan irányelveket mutatva fel, melyek a nyelvtörténeti gondolkodás számára alapvetőek és rendkívül termékenyek. 
Hasonló a másik cikk is (BÁRCZI 1975a), melyben a -ja személyrag $j$ elemét egyszerü hiátustöltőként magyarázza: a lényeg itt egy funkcionális probléma megoldása, melyet egy múlt idejü és egy jelen idejü, -á alakú igei toldalék alaki egybeesése okozott.

E két írás számomra a magyar történeti morfológia egy-egy gyöngyszeme. KoszTOLÁNYI stíluseszményét juttatja eszembe, aki ilyen szellemben oktatná elképzelt tanítványait: „Megmagyaráznám nekik, hogy mindig úgy kell írniok, mintha nem volna idejük, torkukon volna a kés, és haláluk előtt csak pár pillanatot kapnának, hogy valljanak legbensőbb titkukról" (KOSZTOLÁNYI 1932/1971: 171-172). Úgy vélem, BÁRCZI fenti publikációinak talán ez a titka: sietett közkinccsé tenni régóta meglevő, a tanítás során sokszor előadott, de még megíratlan ötleteit - s ennek jegyében a tömörségnek olyan fokára jutott el, ami még az ő mércéjével mérve is kivételes.

S z ó k é s z l e t t a n. - A Magyar Szófejtő Szótár keletkezéstörténetét BÁRCZI (1966) maga összegezte a Szótártani tanulmányokban: egy Pintér Jenő által tervezett értelmező szótár szócikkeinek végéhez írt volna rövid, egy-két szavas etimológiai minősítéseket. Az eredeti terv meghiúsult, elkészült viszont, az összegyült cédulákból kiindulva, a magyar nyelv első teljes etimológiai szótára. Mindez egyetlen ember munkájának eredményeképpen, rövid másfél év alatt. (Hozzá kell tenni, ahogy Bárczi is teszi: a filológiai ellenőrzés munkálataiban felesége is részt vett; az adatok nagy pontossága neki is köszönhető.) Csak csodálni lehet mind Bárczi munkatempóját, mind a mủ szellemét. - A munkatempóról be is számol egy hosszú lábjegyzetben (i. m. 27), melyből kiderül, hogy kis- és nagyvakációit, szabadidejének szinte teljességét (reggel 8-tól este 8-ig vagy inkább este 10-ig) e munkára fordította; ugyanígy a villamosozást és az iskolai tízperces szüneteket is. - Ami pedig a mű szellemét meghatározza, az a kivételes áttekintőképesség, a kritikai szellem és az arányosság. Megmutatkozik itt Bárczi egyik legjellemzőbb iránya: a szintézisalkotás. Idézem BENKÖ LORÁNDnak az életmü egészére vonatkozó véleményét: „Aligha tévedünk, ha azt mondjuk, hogy SIMONYI és GOMBOCZ mellett ő a magyar nyelvtudomány legjobb szintézis-alkotója" (BENKÖ 1963: 13).

A Szófejtő Szótár kapcsán figyelemre méltó még, hogy szerkesztője mindig tekintettel van a laikus olvasóra. Söt, gondol a stílus kérdéseire is. Egy szótár esetében ez elég kivételes, ám annál érdekesebb. Jelzi például, hogy ha minden szócikkben egy elöre felállított sémát követett volna, akkor ,a szótár elképzelhetetlenül sivár lenne” (i. m. 23). A változatosságnak, a csínnak ez az igénye ismét nagyon jellemző rá.

Lexikográfiai tevékenységének újabb mérföldkövét jelzi a hét kötetes Értelmező Szótár, melynek szerkesztési munkálatait ORSZÁGH LÁSZLÓval BÁRCZI vezette. Emellett ő volt, egy személyben, a TESz. általános lektora: az egyetlen személy a föszerkesztő mellett, aki a szótár valamennyi szócikkét látta és kritikus szemmel értékelte.

A szókészlettan körébe vág nyelvtörténeti kézikönyve is: A magyar szókincs eredete (BÁRCZI 1958c). Ez ismét nagyszabású, máig ható szintézis. Felvetettem magamban a kérdést: született-e korábban hasonlóan átfogó mü a magyar szókészlet eredetbeli rétegeiről? Arra jutottam, hogy nem volt ilyen: e téren BÁRCZI fektette le az alapokat. Ez a tankönyv ismét kezdőpontja egy olyan sorozatnak, melyet egymást követő tankönyvfejezetek alkotnak mind a mai napig.

Mivel ez az utolsó kötet, amely az Egyetemi Magyar Nyelvészeti Füzetekben tőle napvilágot látott, érdemes felvetni a következő kérdést: milyen típusú (milyen „,müfajú”) munkákat képvisel ez a sorozat? Magamban egyszer arra jutottam, hogy ezek kézikönyv 
értékü tankönyvek. A szakirodalomban hasonló állásfoglalással találkoztam SzATHMÁRI ISTVÁN (1995: 48) Bárczi-monográfiájában. Ö így mutatja be ezeket: „egyetemi tankönyvei vagy inkább kézikönyvei”. Érdemes eltűnődni ennek kapcsán azon, hogy a tankönyvírás nemcsak pedagógiai, hanem elsőrendü tudományos feladat is, különösen amikor egy-egy tudományterület első szintézise tankönyv formájában lát napvilágot. Számos további példát találunk erre az említett sorozatban. KNIEZSA 29 oldalas müve az első teljes magyar helyesírás-történet, BARTHA KATALIN szintézise a magyar szóképzés történetéröl és BERRÁR JOLÁNÉ a magyar történeti mondattanról szintén máig használt, megkerülhetetlen kézikönyv. Tudjuk, hogy az egyetemi tankönyvek írásának ma milyen alacsony a presztízse a hivatalos értékelésben - a fenti példák világosan mutatják, hogy ez a felfogás alapvetően téves.

N é v t a n. - Az előbbi tankönyvben szerepel egy 40 lapos fejezet is, mely A tulajdonnevek címet viseli (BÁRCZI 1958c: 122-162). Ennek kapcsán két mozzanatot emelnék ki. Egyrészt: az adott területnek ez az első szintézise. Másrészt: A magyar szókincs eredete című könyvben jelent ez meg, annak záró fejezeteként. Megjelenhetett volna önállóan is! A döntés világosan tanúskodik BÁRCZI felfogásáról, mely szerint a név a nyelvi jelek közé tartozik, így annak története a nyelvtörténeten belül tárgyalható.

Árpád-kori nyelvemlékek feldogozás a. - Két alapmü jelzi BÁRCZI munkásságának ezt az irányát. A Tihanyi alapítólevélről írt munkájában (1951a) a szempontok egész sora találkozik: a hangtörténet (s a vele szorosan összefüggő helyesírástörténet), az alak- és mondattan, a szótörténet és az etimológia, s természetesen a névtan, mely az egyes helynevek elemzése során azok lokalizálására is nagy figyelmet fordít. E mü kulcsfontosságú szerepet játszik abban, hogy mit tudunk a 11. század nyelvéröl. BENKÖ LORÁND (1963: 10) egy köszöntő írásában így jellemzi: „szinte egy ómagyar nyelvtan erejével hat az olvasóra”. - A Halotti Beszédről írt könyv (BÁRCZI 1982), melynek szövegét először szemináriumi óráin adta elő, hasonló hatást kelt. Én Bárczit egy ilyen óráján ismertem meg, I. éves koromban. Emlékszem, egy dupla óra egyetlen főhőse ez a szó volt: „Látjátok”. Annyit még hozzáfüznék e témához, hogy élete vége felé egy riporter föltette Bárczinak a kérdést: min dolgozik most? Ö így felelt: egy ómagyar nyelvtanon, bár aligha lesz ideje ezt befejezni... Sajnos így is lett. De jó tudni, hogy ilyen tervek foglalkoztatták, mielőtt elment. Temetésének megrendítő pillanata volt, amikor ott és akkor felhangzott a Halotti beszéd.

Kiemelem még egy közleményét, mely az Ómagyar Mária-siralommal kapcsolatos, s különösen jellemző rá (BÁRCZI 1947). Arról tanúskodik, hogyan járt utána magánemberként annak, hogy az 1940-es leuveni könyvtárégésben valóban elpusztult-e az Ómagyar Mária-siralom (ahogy mindenki hitte), vagy esetleg megmaradt, ahogy egyedül Pais Dezső remélte. Pais fogalmazott meg egy gondolatot, mely valósággal a remény krédója lehet: amíg nem biztos, hogy elpusztult, addig remélni kell, hogy megmaradt.

Nye lvjárástan ( leíró és történe ti). - Ennek a területnek a müvelése szorosan kapcsolódik Debrecenhez, a Csüry Bálinttól kapott örökséghez, amelynek megőrzését és továbbvitelét Bárczi szívén viselte. Itt kezdi meg A magyar nyelvjárások atlasza munkálatainak megszervezését, mely a koncepció kidolgozását és számtalan konkrét teendő kimunkálását is jelenti. Tudjuk, hogy az Új magyar tájszótár kezdeményezése is tőle származik. Mindezek mellett személyes kutatásaiban felfedez egy új tudományterületet: a történeti nyelvjáráskutatást.

A n y elvválto za to k iránti érdeklődése azonban korábbi keletü. Úgy sejtem, ebben francia tájékozottsága is szerepet játszik, akárcsak a nyelvföldrajzzal kapcsolatban. Bárczit a „pesti nyelv” és általában a városi nyelv különösen érdekli - mint olyan 
nyelvváltozat, amely sokféle helyről származó egyének nyelvhasználatából áll elő, s melynek így sajátos belső mozgása van. Figyelt a tolvajnyelvre, s nem számüzte szótárából az ún. illetlen szavakat sem. Azt vallotta ugyanis, hogy a nyelvésznek az egész életet magához kell ölelnie.

A stilisztika és a ny elvművelés szintén közel állt hozzá, amint erről számos írása tanúskodik (vö. tanulmányainak posztumusz kötetét, BÁRCZI 1980). Az eszperantó iránti elkötelezettségének ugyancsak hangot adott idős korában is.

Tudományos munkák a müvelt nagyközönség számára. - Itt életének egyik fő művéhez érünk. A magyar nyelv életrajza (BÁRCZI 1963) a magyar nyelvről írt legszebb könyvek egyike. Egyedülálló abban, hogy bámulatos egyensúlyt tud teremteni két eltérő követelmény között: az egyik a legmagasabb tudományosság igénye, a másik a közérhetőség, sőt olvasmányosság. Mi a titka ennek a nem könnyü egyensúlynak? Szerepet játszik ebben az anyag elrendezésmódja: korszakról korszakra haladva mutatja be a nyelv alakulását, végig beleillesztve azt egy tágabb történeti, müvelődéstörténeti és irodalomtörténeti kontextusba. Mindez épít az olvasó ismereteire és érdeklődésére. Maguk a részfejezetek rövidek, egy-két laposak, és füzérszerúen követik egymást; éppen ezért külön-külön is tanulmányozhatók. Ezt a könyvet szinte úgy lehet használni, ahogy az ember felüt egy szótárt, hogy benne egy adott kérdésről minden lényeges tudnivalót megtaláljon. Egészében igazán olvasóbarát; sokkal inkább az, mint nyelvtörténeti szakirodalmunk legtöbb darabja. Külön kiemelem, hogy van benne szó röviden nyelvünk eredetéről és a nyelvrokonság kritériumairól is (ami közérdekű kérdés) - és hogy egyes későbbi, elhanyagolt korszakokról is az ismeretek sokaságát adja. Ilyen a középmagyar kor, melynek 100 lapos fejezete többek közt az írott nyelvi norma alakulását is elemzi, nagy mértékben építve a misszilisek tanúságára (ami egészen új irány ekkor); részletes tárgyalásban részesül az újmagyar kor is, mely a nyelvtörténeti vizsgálatoknak mindmáig a mostohagyereke maradt. Szintézist írni részletes előtanulmányok nélkül igen nehéz; Bárczinak sok hiányt kellett pótolnia ahhoz, hogy müve ilyen egységes legyen. Végül kiemelem azt az arányérzéket, amellyel az adatokat beépíti a gondolatmenetbe: bizonyító erejük megvan, de közben a gondolat mozgékonyan (Bárczi egyik kedves szavával: fürgén) halad a maga útján. Ebben persze a stílusnak is szerepe van, amelyről (Buffon óta) tudjuk, hogy maga az ember. Ez a könyv a maga 500 oldalával alighanem Bárczi leghosszabb mủve - ám ha meggondoljuk, hogy teljes magyar nyelvtörténetet ad, ez is nagyon tömörnek mondható.

A sumer-magyar nyelvrokonságról írott cikke (BÁRCZI 1975b) ugyancsak példaértékü. Első helyen talán azért, mert tiszteli laikus olvasóját, feltételezi róla, hogy nyitott a logikus érvekre és kíváncsi az igazságra. Érvel tehát, tudományos alapelveket oszt meg, cáfol is tarthatatlan nézeteket - mindezt olyan hangnemben, amely közös gondolkodásra hív. Az egyik befejező mondata szerint: „Ha a magyarság meg akarja állni a helyét a történelem színpadán, le kell mondania a délibábok kergetéséről, és a realitások, a valóság, az igazság talaján kell megállnia" (i. m. 197). Eszünkbe juthat e cikk olvasása során KoszTOLÁNYInak A magyar nyelv helye a földgolyón címú írása (1930/1971), mely ugyancsak a szenvedélyes igazságkeresés példája, s melyben ugyanúgy együtt van a hamis állítások cáfolata, a szellemi elegancia és a magyar nyelv iránti szeretet.

4. Tevékenysége a Magyar Nyelvtudományi Társaságban és a tudományos életben. A jelen alkalom ráirányítja a figyelmet a következő kérdésre: milyen szerepet ját- 
szott Bárczi Géza a Társaságban? Arra nézve, hogy milyen tisztségeket viselt, SzATHMÁRI ISTVÁN könyvében (2015: 207) találunk pontos választ: Bárczi először a Társaság egyik alelnöke (1944-1948), majd egyik társelnöke (1951-1954, 1956-1957), végül 1959-től 1975-ig a Társaság elnöke volt. 17 éven át töltötte be ezt a tisztséget.

A halála utáni első közgyülésen SZATHMÁRI ISTVÁN (1976: 506) így emlékezett meg róla fötitkári beszámolójában: „Most már megmondhatjuk: eszményi elnöke volt Társaságunknak. Eszményi volt a tudomány felöl nézve: a nyelvészetnek úgyszólván minden ágában otthon volt [...]. Eszményi volt mint oktató-nevelö is [...]. Eszményi volt anyanyelvünk szeretetében [...]. Eszményi volt emberi egyéniségében [...].

Többen felidézhetjük még, hogy milyen kedvvel és odaadással vett részt Bárczi a Társaság kiemelt rendezvényein (Debrecen, Eger, Zalaegerszeg), melyeknek elnöki megnyitóit, zárszóit rendszerint ő tartotta.

Ugyancsak a Társasághoz szorosan kapcsolódó tevékenysége, hogy a Magyar Nyelv szerkesztésében is részt vállalt. 1953-tól a folyóiratot ketten szerkesztik: Pais Dezső és Benkő Loránd. Nem sokkal ez után arra is van példa, hogy egyes számok címlapján három név szerepel: „Szerkesztette Bárczi Géza, Benkő Loránd és Pais Dezső” (1955/1 és 1955/4). A későbbiekben Bárczi mint a szerkesztőbizottság harmadik tagja jelenik meg a címlap belső oldalán. Ugyancsak tagja lett a Magyar Nyelvőr szerkesztőbizottságának is. Ilyen feladatokat gyakran vállalt, mivel őt a közjó szolgálata vezette, s minden jó ügyet támogatott.

A tudományos közéletben meghatározó szerepet játszott: így az Akadémia I. Osztályán, a Nyelvtudományi Bizottságban és más bizottságokban. Részt vett az Anyanyelvi Konferenciák elindításában, s ezek elnöke is lett, mivel fontosnak tartotta a magyarokkal és a magyar nyelvvel való törődést a nagyvilágban. Számos előadást tartott a TIT-ben, s végtelen készséggel tett eleget minden meghívásnak a tudományos ismeretterjesztés terén. BENKÖ LORÁND (1976: 2) joggal mondta búcsúztatójában: fel kell idézni mindazt, ,amit közelebbről a magyar nyelvtudományért, tágabb értelemben a magyarság szellemi müveltségének emeléséért tett."

5. Bárczi tanár úr, a nevelő. Középiskolai tanárságáról jellemző emlékeket gyüjtött össze SzATHMÁRI ISTVÁN (1995: 29-33). Én most Debrecennel kezdeném, ahol a legszorosabb tanítványi kör kialakult. E körbe tartozott E. Abaffy Erzsébet, B. Lőrinczy Éva, Papp László, P. Hidvégi Andrea és Szathmári István. Bárczi hívására, sőt rábeszélésére hozzájuk csatlakozott D. Bartha Katalin is, miután 1947-ben sikerült visszatelepülnie Kárpátaljáról. Mindezek a munkatársak vele jöttek Budapestre is. Abaffy Erzsébet és Bartha Katalin az egyetemen dolgozott mellette. Szathmári István 1955-ben szintén a Bárczi-tanszék tagja lett, s 1970-től ő lett a vezetője a Mai Magyar Nyelvi Tanszéknek.

E tudományos közösségben egyedülállóan bensőséges, családias szellem alakult ki. BÁRCZI így emlékezett erre Debrecenben 1973-ban, amikor díszdoktorrá avatták (vö. SEBESTYÉN 1973: 4): „A hallgatósággal hamar megbarátkoztam”; „kizárólag itt éltem az egyetemen”; ,a tanszéken igen komoly munka folyt, a könyvtár állandóan használatban volt. De ez a munka valahogy könnyed, derüs volt, nem volt benne kényszeredettség! Szobám mellette állt a szemináriumnak, minduntalan kijöttem, megnéztem, ki mit dolgozik, segítettem, ha elakadt, és ilyen módon a hallgatókban is felkelt a bizalom a tanszék iránt." Majd így folytatja: ,az a szerencsém volt, hogy nagyon sok tehetséges tanítványom akadt, akikkel öröm és élvezet volt együtt dolgozni”. Utolsó interjúja végén ismét visszatér tanít- 
ványaira: felidézi azt, hogy számos hallgatója ,elökelő helyet foglal el a magyar nyelvtudományban, annak szorgalmas, hasznos munkása”. Majd ennyit füz hozzá: „és azt hiszem, hogy ebben egy kicsi részem legalábbis nekem is volt" (BOLLA szerk. 1994: 5). A stílus jól mutatja azt a végtelen előzékenységet, amely a másokhoz való viszonyát jellemezte. Ez az interjú három héttel halála (1975. november 7.) elött készült.

Budapesti korszakára térve: előadásai nagy évfolyamoknak szóltak; emellett itt is kialakult szemináriumi hallgatóinak hozzá ragaszkodó köre.

Milyenek voltak a Bárczi-órák? Előadásmódja egyszerre volt végtelenül természetes és magától értetődően elegáns. Minden szava világos volt, tömör és érzékletes; együtt lehetett gondolkodni vele. Saját személyét soha nem helyezte elötérbe: őt a tudományos igazság érdekelte. Nagy figyelemmel kísérte diákjai munkáját. Dialógusba lépett velük, s ez akkor is érezhető volt, amikor előadást tartott. A nagy előadás is dialógus! - szürtem le később, amikor saját tapasztalatokat szereztem e téren.

Magam sok-sok kedves emléket őrzök róla. Ezeket megosztottam egy síkfőkúti előadás keretében (KOROMPAY 2018), valamint egy francia nyelvü interjúban (TAMUSSIN 2018: Annexe F3, 710-715). Most csak kettőt idéznék fel közülük. Hajdani diákköri dolgozatom margójára - egy középkori névadás szövevényes szakirodalmi magyarázata mellé - ezt írta: „ezt persze nem hiszem, de mindegy”. Jellemző ez a nagyvonalú „de mindegy"... Másrészt kiemelném egy hosszú előadása záró gondolatát, mely sokféle, egymással ütköző szempont mérlegelése után így hangzott: „nem szabad, hogy a módszer gondolkodjék a kutató helyett”. Ez a mondat a személyes felelősségre tanít.

Bárczi tanár úrra visszagondolva ilyennek látom öt: összhangban volt önmagával, nyitott volt mások iránt, és szerette az életet. Tehát boldog ember volt. Tudósi és tanári munkájában együtt volt a gondolkodás szabadsága, a kutatói szenvedély és a tudomány közvetítésének öröme. Ezek olyan értékek, melyeket jó megőrizni és fontos továbbadni.

Kulcsszók: magyar nyelvtörténet, szintézisalkotás, etimológiai szótár, Debreceni Egyetem, ELTE.

\section{Hivatkozott irodalom}

E. AbAFFy ERZSÉBET - NAGy FERENC - ZELLIGER ERZSÉBET szerk. 1973. Adalékok a magyar nyelv életrajzához. ELTE Nyelvtudományi Dolgozatok 14. ELTE, Budapest.

BÁrcZI GÉZA 1933. Ó-francia hang-és alaktan. Danubia, Pécs-Budapest.

BÁRCZI GÉZA 1938. A magyar nyelv francia jövevényszavai. A Magyar Nyelvtudomány Kézikönyve. MTA, Budapest.

BÁRCZI GÉZA 1947. A Leuveni Kódex történetének legújabb szakasza. Magyar Nyelv 43: 301-305.

BÁRCZI GÉZA 1951a. A Tihanyi apátság alapitólevele mint nyelvi emlék. Akadémiai Kiadó, Budapest.

BÁRCZI GÉZA 1951b. Fonetika. Egyetemi Magyar Nyelvészeti Füzetek. Tankönyvkiadó, Budapest. BÁRCZI GÉZA 1953. Bevezetés a nyelvtudományba. Egyetemi Magyar Nyelvészeti Füzetek. Tankönyvkiadó, Budapest.

BÁRCZI GÉZA 1956. Pais Dezső. In: BÁRCZI GÉZA - BENKÖ LoRÁND szerk., Emlékkönyv Pais Dezső hetvenedik születésnapjára. Akadémiai Kiadó, Budapest. 9-22.

BÁRCZI GÉZA 1958a. Magyar hangtörténet. Második, bővített kiadás. Egyetemi Magyar Nyelvészeti Füzetek. Tankönyvkiadó, Budapest. 
BÁRCZI GÉZA 1958b. Magyar történeti szóalaktan I. A szótövek. Egyetemi Magyar Nyelvészeti Füzetek. Tankönyvkiadó, Budapest.

BÁRCZI GÉZA 1958c. A magyar szókincs eredete. Második, bővített kiadás. Egyetemi Magyar Nyelvészeti Füzetek. Tankönyvkiadó, Budapest.

BÁrCZI GÉZA 1963. A magyar nyelv életrajza. Gondolat Kiadó, Budapest.

BÁRCZI GÉZA 1966. A Magyar Szófejtő Szótár lexikográfiai elvei. In: OrSZÁGH LÁszLó szerk., Szótártani tanulmányok. Tankönyvkiadó, Budapest. 9-28.

BÁRCZI GÉZA 1973. A magyar föltételes mód jelének eredetéhez. Magyar Nyelv 69: 210-212.

BÁRCZI GÉZA 1975a. A tárgyas -ja -i személyrag. Magyar Nyelv 71: 129-131.

BÁRCZI GÉZA 1975b. A sumir-magyar nyelvrokonság kérdése. Látóhatár 1975/1: 188-197.

BÁRCZI GÉZA 1976. Emlékek egy könyv olvasása közben. Irodalomtörténet 1976/1: 88-100.

BÁRCZI GÉZA 1980. A magyar nyelv múltja és jelene. A kötet anyagát összeállította és szerkesztette PAPP LÁsZLÓ. Gondolat, Budapest.

BÁrCZI GÉZA 1982. A Halotti Beszéd nyelvtörténeti elemzése. Sajót alá rendezte és szerkesztette E. ABAFFY ERZSÉBET - N. ABAFFy CsILlA. Akadémiai Kiadó, Budapest.

BÁRCZI GÉZA 1990. A magyar igeragozás története. Sajtó alá rendezte és szerkesztette E. ABAFFY ERZSÉBET és N. ABAFFY CSILlA. Nyelvtudományi Értekezések 130. Akadémiai Kiadó, Budapest.

BÉKÉSI IMRE - H. TÓTH IMRE szerk., 1994. Bárczi Géza centenárium. Magyar Tudományos Akadémia Szegedi Területi Bizottsága IV. Szeged.

BENKŐ LORÁND 1963. Bárczi Géza hetven éves. In: BENKŐ-LigeTI-PAIS szerk., 5-15.

BENKÖ LORÁND 1976. Búcsú Bárczi Gézától. Magyar Nyelv 72: 1-4.

BENKŐ LORÁND - LIGETI LAJOS - PAIS DEZSÖ szerk. 1963. Tanulmányok a magyar nyelv életrajza köréböl. Nyelvtudományi Értekezések 40. Akadémiai Kiadó, Budapest.

Bolla KÁLMÁn sorozatszerk. 1994. Bárczi Géza (1894-1975). A hetvenes évek magyar nyelvészei. Pályaképek és önvallomások 4. ELTE Fonetikai Tanszék, Budapest.

FERENCZ GYŐZŐ 2009. Radnóti Miklós élete és költészete. Osiris Kiadó, Budapest.

Gombocz Zoltán 1924. Ferdinand de Saussure: Cours de linguistique générale. Magyar Nyelv 20: $141-143$.

JENEY ÉVA 2015. Marginália a Fekete kolostorhoz. Bárczi Géza lapszéli jegyzetei. Ex Symposion 90. http://real.mtak.hu/30500/1/Barczi_exsympo_jeneye.pdf (2020. 03. 09.)

KÁLMÁN ANDRÁs - SZABICS IMRE 1988. Bárczi Géza romanisztikai munkássága. A nyelvtudomány és a nyelvoktatás mühelyéből 7. ELTE, Budapest.

KOROMPAY KLÁRA 2018. Emlékeim Bárczi tanár úrról. Helynévtörténeti Tanulmányok 14: 117-126.

KosZTOLÁNYI DezSŐ 1930/1971. A magyar nyelv helye a földgolyón. In: Nyelv és lélek. Szépirodalmi Könyvkiadó, Budapest. 89-108.

KoszTOLÁNYI DEZső 1932/1971. Egy és más az írásról. In: Nyelv és lélek. Szépirodalmi Könyvkiadó, Budapest. 171-174.

Lörinczi László 1975. Utazás a Fekete kolostorhoz. Kriterion, Bukarest.

PAIs Dezső 1964. Bárczi Géza ünneplése. Magyar Nyelv 60: 129-136.

SEBESTYÉN ÁRPÁD 1973. Bárczi Géza köszöntése. Magyar Nyelvjárások 20: 3-7.

SZATHMÁRI ISTVÁN 1976. A Magyar Nyelvtudományi Társaság LXXII. közgyülése. Főtitkári beszámoló. Magyar Nyelv 72: 506-510.

SZATHMÁRI ISTVÁN - E. ABAFFY ERZSÉBET - B. LÖRINCZY ÉVA szerk. 1994. Bárczi Géza emlékkönyv. A Magyar Nyelvtudományi Társaság Kiadványai 200. Magyar Nyelvtudományi Társaság, Budapest.

SZATHMÁRI ISTVÁN 1995. Bárczi Géza. A múlt magyar tudósai. Akadémiai Kiadó, Budapest.

SZATHMÁRI ISTVÁN 2015. A Magyar Nyelvtudományi Társaság története (1904-2005). Magyar Nyelvtudományi Társaság -Tinta Könyvkiadó, Budapest. 
TAMUSSIN, CATHERINE 2018. La didactique du français dans la Hongrie de l'entre-deux-guerres: acteurs, outils, représentations. Linguistique. Université Sorbonne Paris Cité. PhD-disszertáció. Paris. https://tel.archives-ouvertes.fr/tel-02081516/document (2020. 03. 11.)

\section{Géza Bárczi was born 125 years ago}

Géza Bárczi is a prominent figure of Hungarian linguistics; he had an influential role in the history of that discipline both as a professor and as a researcher. The present commemoration was written by one of his former students, someone who knew him closely and finds it important to pass on the memory of her mentor. The paper enumerates the main events of Géza Bárczi's professional life (from being a secondary school teacher to leading the department of Hungarian linguistics at the University of Debrecen and then at ELTE) and gives a broad picture of the various areas of his work, which covers almost all of the subfields of Hungarian language history (such as phoneme history, historical morphology, lexicology etc.). Géza Bárczi is also considered to be a great synthesis maker, something which particularly shows up in two of his works: he is the author of the first thorough etymological dictionary of the Hungarian language (1941) and of an extensive monograph called A magyar nyelv életrajza (A Biography of the Hungarian Language). He also had an important role in the Society of Hungarian Linguistics, of which he was the president for 17 years. His lectures were unforgettable experiences for his students: he was always seeking for the truth in his research and his way of presentation was always known for its crystal clear logic and elegant style.

Keywords: history of the Hungarian language, synthesis making, etymological dictionary, University of Debrecen, ELTE.

KOROMPAY KLÁRA

ELTE Eötvös Loránd Tudományegyetem

\section{SZEMLE}

\section{Fóris Ágota - Bölcskei Andrea szerk., Terminológiastratégiai kihívások a magyar nyelvterületen}

L'Harmattan - OFFI Zrt., Budapest, 2019. 218 lap

1. Az ismertetett tanulmánykötet azon három köszöntő és nyolc előadás írott változatát tartalmazza, amelyek az azonos címü, 2018. március 9-én megtartott konferencián hangzottak el, valamint az EAFT által közzétett Brüsszeli nyilatkozat és az UNESCO által megjelentetett Terminológiapolitikai irányelvek magyar fordítását foglalja magában. A köszöntőket a magyar terminológiastratégiával intézményi szinten is foglalkozó jelentős magyar szervezetek vezetői mondták; az előadók, egyben a tanulmányok szerzői pedig a szakterület elismert kutatói, illetve intézmények, szervezetek vezetői (magyarországi, felvidéki, erdélyi egyetemek, kutatóintézetek, az Európai Terminológiai Társaság [EAFT] és a Magyar Nyelv Terminológiai Tanácsa [MaTT] képviselöi). A kötet témái az általános 